\title{
Amanita psammolimbata, a new species from Northeastern Brazilian sand dunes
}

\author{
Wartchow $\mathrm{F}^{1 *}$, Sulzbacher MA ${ }^{2}$, Baseia $\mathrm{IG}^{3}$ \\ ${ }^{1}$ Universidade Federal da Paraíba, Departamento de Sistemática e Ecologia/CCEN, CEP: 58051-970, João Pessoa, \\ PB, Brazil. \\ ${ }^{2}$ Universidade Federal de Pernambuco, Departamento de Micologia, Programa de Pós-Graduação em Biologia de \\ Fungos, Av. Nelson Chaves s/n, 50760-420, Recife, PE, Brazil. \\ ${ }^{3}$ Universidade Federal do Rio Grande do Norte, Departamento de Botânica e Zoologia/CB, CEP 59072-970 Natal, Rio \\ Grande do Norte, Brazil.
}

Wartchow F, Sulzbacher MA, Baseia IG. 2015 - Amanita psammolimbata, a new species from Northeastern Brazilian sand dunes. Mycosphere 6(3), 260-265, Doi 10.5943/mycosphere/6/3/3

\begin{abstract}
Amanita psammolimbatula is described as a new species occurring on the sand dunes with 'restinga' vegetation from Rio Grande do Norte State, Brazil. This new and uncommon taxon is diagnosed by the small basidiomes (up to $42 \mathrm{~mm}$ in diam.), brownish yellow to pale whitish yellow toward margin, white lamella and stipe, white unchanging context, lack of narrow groove between the universal veil and the stipe base in the immarginate bulb, and basidiospores (8-) 9-11.5 $\times 5-7$ $(-7.5) \mu \mathrm{m}$. Description, discussion, photograph and drawings of the new species are given.
\end{abstract}

Key words - Amanitaceae - Basidiomycota - Neotropics - taxonomy

\section{Introduction}

Studies on Amanita Pers. (Amanitaceae) recently gave more attention, with new records and new species being described or cited from Northeast Brazil (Wartchow \& Maia 2007, Wartchow et al. 2007, 2009, 2013, Menolli et al. 2009). In the sand dune habitat, Amanita viscidolutea Menolli, Capelari \& Baseia was recently described (Menolli et al. 2009). Amanita is an ectomycorrhizal genus (Smith \& Read 2008, Tedersoo et al. 2010); however some species are most certainly nonectomycorrhizal (Wolfe et al. 2012a, b). Recently, several unidentified Amanita specimens were also reported from a sand dune forest where this genus is very abundant (Sulzbacher et al. 2013).

Thus, here we describe a new Amanita species from Northeast Brazilian sand dunes in 'restinga' vegetation, thereby increasing knowledge of this genus in Brazil.

\section{Materials \& Methods}

The new species was collected at 'Parque Estadual das Dunas de Natal', municipality of Natal $\left(5^{\circ} 48^{\prime} \mathrm{S}-5^{\circ} 43^{\prime} \mathrm{S}\right.$ and $\left.35^{\circ} 09^{\prime}-35^{\circ} 12^{\prime} \mathrm{W}\right)$, a 'restinga' forest in the State of Rio Grande do Norte, Northeast Brazil (Almeida et al. 2006). The area contains elements of Atlantic Forest mixed with some species in common with Caatinga and Coastal Tableland, where species of Leguminosae Juss. (all subfamilies), Myrtaceae Juss., Poaceae Barnhart, Asteraceae Bercht. \& J. Presl. and Euphorbiaceae Juss. predominate (Freire 1990). Color codes follow Kornerup and Wanscher (1978). Generic and infrageneric names and concepts follow Corner \& Bas (1962) and Bas (1969) 


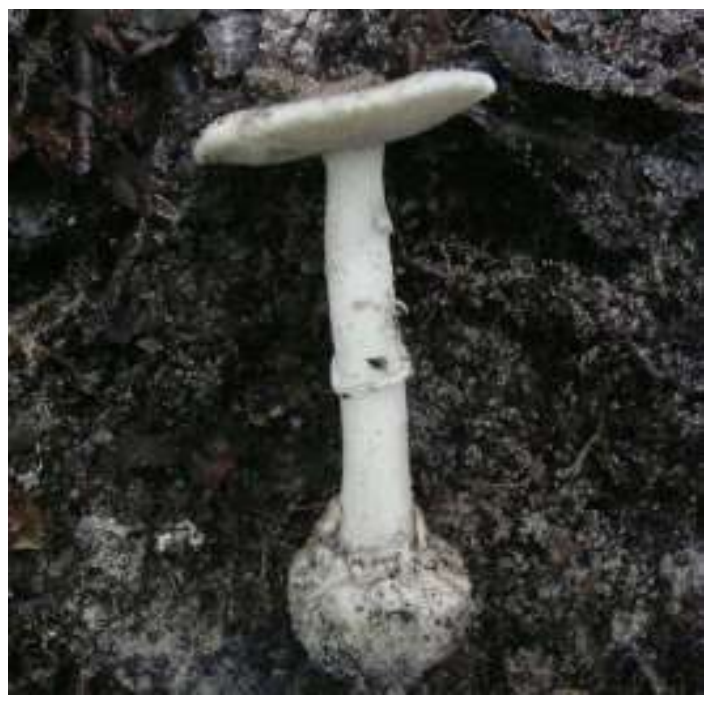

Fig. 1 - Basidiome of Amanita psammolimbatula. Bar= 20 mm. Photo: M.A. Sulzbacher.

as modified by Yang (1997). We follow the emended methodology of Tulloss (2000) for biometric measurements and biometric variable names which are summarized by Tulloss and Lindgren (2005).

The holotype is deposited at UFRN-Fungos and isotype at JPB (Thiers 2015).

\section{Taxonomy}

Amanita psammolimbata Wartchow \& Sulzbacher, sp. nov.

Figs. 1-9

MycoBank 811693

Diagnosis - Amanita psammolimbata is characterized by the basidiome stature, buff-yellow or paler tints on pileus, immarginate bulb not showing a narrow groove between the universal veil and the stipe base, basidiospores (8-) 9-11.5 × 5-7 (-7.5) $\mu \mathrm{m}$ and clampless basidia.

Typus - BRAZIL. Rio Grande do Norte, Natal, Parque Estadual das Dunas de Natal, Trilha da Geologia, 10.V.2011, M.A. Sulzbacher MAS 325 (UFRN-Fungos 1870 holotypus hic designatus!; JPB 60531 isotypus!).

BASIDIOME small size, solitary. PILEUS: to $42 \mathrm{~mm}$ wide, plane-convex, buff-yellow (K\&W 4C4 'blond') to olive brown (K\&W 4D5), pale yellowish white (K\&W 2A2) toward margin; margin smooth, without obvious appendiculate ornaments; surface smooth, dry; universal veil as single whitish (1A1) patch up to $7 \times 6 \mathrm{~mm}$ near centre; context up to $4 \mathrm{~mm}$ at center, turning gradually thinning to margin, white, unchanging. LAMELLAE: nearly free, subclose close to subcrowded, white (1A1) with smooth edge, up to $4 \mathrm{~mm}$ diam. (at the central lamellae); lamellulae truncate, with different sizes. STIPE: 59 (excluding bulb) $\times 9 \mathrm{~mm}$ (at midstipe), cylindric; surface squamulose; context is hollow in the bulb and solid at the apex region; bulb turnip-shaped up to 19 $\mathrm{mm}$ long and up to $21 \mathrm{~mm}$ wide; context solid, greenish grey (1C2); universal veil as short limb about $8 \mathrm{~mm}$ high at the bulb near junction to stipe base, not showing a narrow groove, white, unchanging, submembranous; partial veil very fragile, fugacious near tip. Odor and taste not performed. Spore print not seen.

BASIDIOSPORES: [30/1/1] (8-) 9-11.5 × 5-7 (-7.5) $\mu \mathrm{m},(\mathrm{L}=10.1 \mu \mathrm{m} ; \mathrm{W}=6.3 \mu \mathrm{m} ; \mathrm{Q}=$ (1.33-) 1.34-1.83 (-1.91); $\mathbf{Q}=1.61$, amyloid, hyaline, colorless, broadly ellipsoid to sometimes ellipsoid, usually adaxially flattened, smooth with thin walled; content as one large guttule; apiculus obtuse, small, sublateral to subapical. BASIDIA: 35-47 × 10-12.5 $\mu \mathrm{m}$, clavate, bearing four sterigmata up to $5 \mu \mathrm{m}$ high, clampless. SUBHYMENIUM: cellular; cells rehydrating well, up to $22 \mu \mathrm{m}$ deep, cellular with frequently 2 or 3 layers of globose, subglobose to broadly clavate cells 9-15 $\times$ 6-12 $\mu \mathrm{m}$, hyaline, thin walled; $\mathbf{w}_{\mathbf{s t}}-$ near $=25-35 \mu \mathrm{m} ; \mathbf{w}_{\mathbf{s t}} \mathbf{- f a r}=30-39 \mu \mathrm{m}$. LAMELLA TRAMA: rehydrating well; $\mathbf{w}_{\mathbf{c s}}=31.5 \mu \mathrm{m}$; common filamentous hyphae $2.5-4.5 \mu \mathrm{m}$ wide and clavate 
elements up to $40 \times 14 \mu \mathrm{m}$; frequent clavate inflated divergent elements, these ranging to $42 \times 14$ $19 \mu \mathrm{m}$ in diam., common. MARGINAL TISSUE OF LAMELLAE: with broadly clavate to pear shape hyaline elements, $19-27.9 \times 10-19 \mu \mathrm{m}$. PILEUS CONTEXT: rehydrating satisfactorily; acrophysalides mostly clavate $72-145 \times 9.5-24 \mu \mathrm{m}$, thin walled, hyaline, plentiful; filamentous hyphae $2.5-6 \mu \mathrm{m}$ wide, frequent, frequently branched and strongly interwoven, forming a loose matrix where other elements occur; vascular hyphae absent. STIPE CONTEXT: rehydrating satisfactorily, longitudinally acrophysalidic; acrophysalides ranging to $300 \times 27 \mu \mathrm{m}$, plentiful, very conspicuous; filamentous hyphae 2.5-3.5 $\mu \mathrm{m}$, mostly longitudinally oriented, clamps absent; vascular hyphae 7-12 $\mu \mathrm{m}$ wide, infrequent. PILEIPELLIS: up to $76 \mu \mathrm{m}$ thick at centre; cutis radially oriented, colorless, $2-4 \mu \mathrm{m}$ wide, not gelatinized. UNIVERSAL VEIL: On pileus: inflated elements 21-45 × 19-34 $\mu \mathrm{m}$, globose, subglobse ovoid to sometime broadly clavate, hyaline, colorless, mostly thin walled; adjacent hyphae short-celled 10-35 $\times 5-6 \mu \mathrm{m}$; filamentous hyphae to $5 \mu \mathrm{m}$ wide, colorless, thin-walled, common, strongly interwoven; vascular hyphae absent. On stipe base: the innermost layer of the limb comprising by abundant globose, subglobose e.g. $18.5-47 \times 13.5-45 \mu \mathrm{m}$ or pear shape elements ranging to $77 \times 65 \mu \mathrm{m}$, with infrequent broadly clavate or balloon shape e.g. $65 \times 42.5$ $\mu \mathrm{m}$ elements, colorless, wall ranging to $0.7 \mu \mathrm{m}$ thick; common filamentous hyphae $2-6 \mu \mathrm{m}$ wide, hyaline, mostly thin-walled, clamp connection absent; vascular hyphae absent; outer layer covere almost exclusively by filamentous hyphae 2.5-3.5 $\mu \mathrm{m}$ wide, colorless, hyaline, thin walled, plentiful; inner surface also covered by hyphae. Limbus internus: interwoven, plentiful filamentous hyphae 2-6 $\mu \mathrm{m}$ wide, hyaline, thin walled; inflated elements scarce frequent, 20-77 × 13.5-65 $\mu \mathrm{m}$; vascular hyphae not observed. PARTIAL VEIL: not observed, collapsed.

Habitat - On soil in coastal sandy dune of Atlantic Forest, surrounded by Coccoloba and other (Freire 1990).

Known distribution - known only from type locality.

Etimology - L., psammus (sandy); 'limbata' (limb bearing volva), meaning 'sandy limbate Lepidella'.

\section{Discussion}

Amanita psammolimbata belongs to Amanita subgen. Lepidella (E.-J. Gilbert) Veselý emend Corner \& Bas (1962), sect. Lepidella, subsect. Limbatulae Bas due the amyloid basidiospores, universal veil as submembranous limb at bulb, ellipsoid to elongate basidiospores and fugacious partial veil (Bas 1969). Among taxa of this subsection, we can assign our new species in the stirp Preissii due the clampless basidia, basidiospores longer than $8 \mu \mathrm{m}$ and the presence of ellipsoid to elongate basidiospores, with ' $Q$ ' value falling into this category (Bas 1969).

Following the key of Bas (1969: 535-536), the immarginate bulb not showing a narrow groove between the universal veil and the stipe base, the small pileus diameter and the nondextrinoid basidiospores contents include our new species in a group with other three taxa:

- Amanita preisii (Fr.) Sacc. from Western Australia shares in the pale pileus, but larger ranging to $80 \mathrm{~mm}$ in diam. Other difference are the napiform bulb stipe base, somewhat larger basidiospores [20/2] (9.5-) 10-12 (-12.5) $\times 5.5-6 \mu \mathrm{m}$ that distinctly range to cylindrical $(\mathrm{Q}=1.70$ 2.20, Qm = 1.90-2.00), and the ramose to subcellular subhymenium (Bas 1969). Wood (1997: 801) reported this name to New South Wales, in the Southeaster Australia with the stipe base 'without free margin or with small but distinct sheathing volva'. It certainly does not belong to subsect. Limbatulae.

- Amanita rosea D.A. Reid and A. luteovolvata O.K. Mill. also are tentatively included in stirp Preissii (amanitaceae.org) but also differ primarily in the following features: A rosea shows pinkish tints on pileus, less prominent bulb and larger basidiospores $(9.5-) 10.2-14(-15) \times(5.5-)$ 6-6.6 (-7.75) $\mu \mathrm{m}$ (Reid 1980) or [25/1/1] (9.5-) 10.9-15.8 ×6.1-8.5 $\mu \mathrm{m}, \mathrm{L}=12.9 \mu \mathrm{m}, \mathrm{W}=7.4$ $\mu \mathrm{m}, \mathrm{Q}=(1.45-)$ 1.49-2.08 (-2.21), $\mathbf{Q}=1.74$ (amanitaceae.org 2014); A. luteovolvata differs in the presence of buff to yellow to orange-buff universal veil on pileus, similar color of universal veil on stipe and larger basidiospores (9-) 10-13 (-14) $\times(5-)$ 5.5-7.5 (-8.6) $\mu \mathrm{m}, \mathrm{Q}=1.43-2.08, \mathbf{Q}=1.62$ (Miller 1992). 

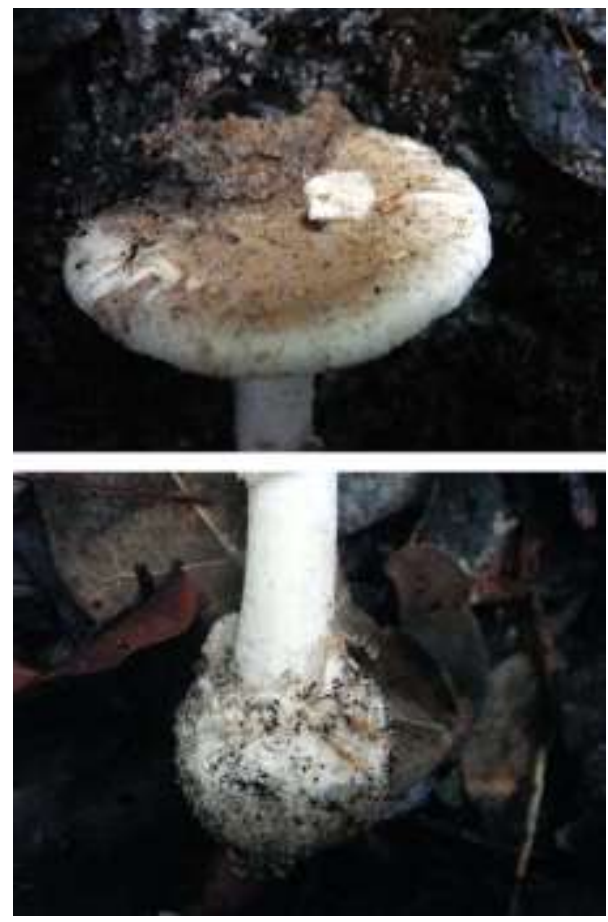

Figs. 2-3 - Amanita psammolimbatula. 2 Detail of pileus surface with patch of universal veil. 3 Details of the bulb showing the limbate universal veil. Bars $=10 \mathrm{~mm}$. Photos: M.A. Sulzbacher.

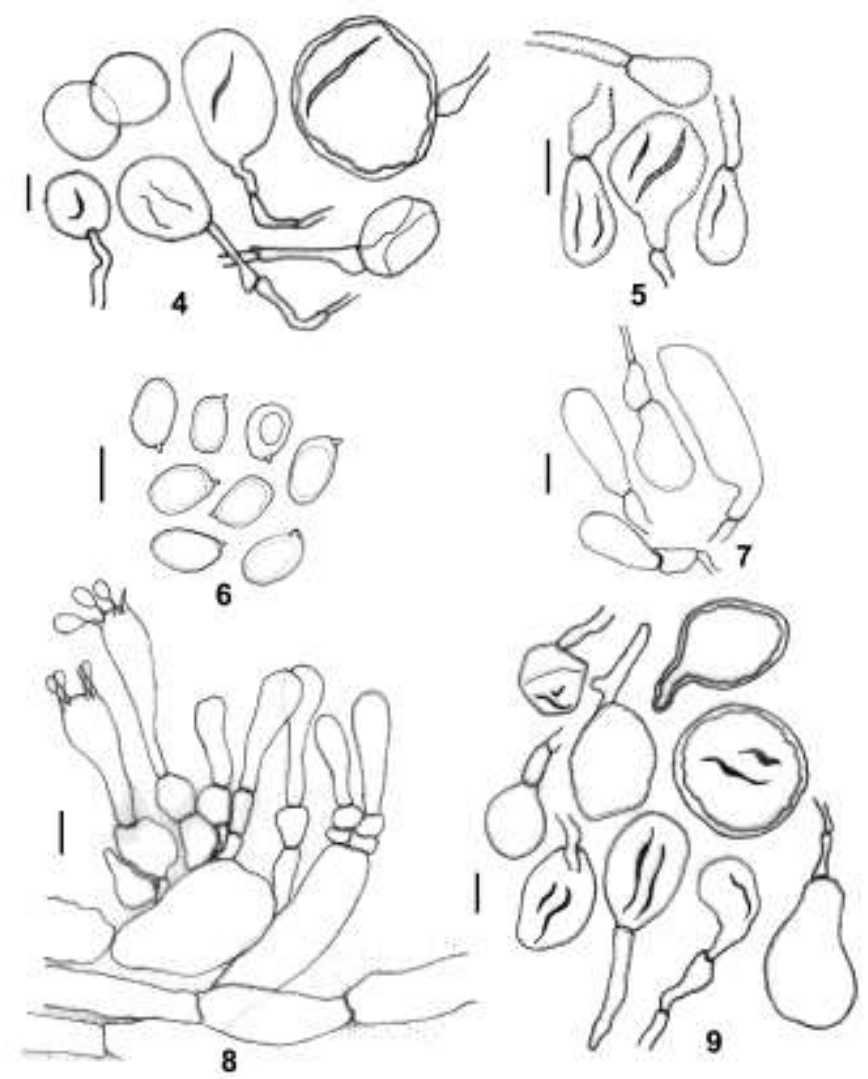

Figs. 4-9 - Amanita psammolimbatula. 4 Elements of the universal veil from the limb (after crushed). 5 Elements of the sterile marginal tissue of the lamella edge. 6 Basidiospores. 7 Elements of the universal veil of the limbus internus. 8 Basidium, basidioles, subhymenium and the lamella trama with inflated elements diverging from it. 9 Elements of the universal veil from pileus patch (after crushed). Bars $=10 \mu \mathrm{m}$. 
Bas (1969: 536) tentatively include A. subalbida Cleland in the key of stirps Preisii, but the type specimen apparently is difficult to interpret (Bas 1969: 502, 510-512). Actually, it is included in subsect. Solitariae Bas stirp Grossa due doubt regarding to the presence of limbate volva. Later collections also reported this species as having with ridge or rim-like volva but sometimes with scales or even lacking (Reid 1980, Grgurinovic 1997, Wood 1997).

\section{Acknowledgements}

The first author thanks Dr. Rodham E. Tulloss (New Jersey) by his guidance in the studies of Amanita. This work was supported by CNPq (PROTAX - Proc. 141073/2006-3) and CAPES for scholarships granted to M. Sulzbacher.

\section{References}

Almeida Jr. EB, Zickel CS, Pimentel RMM. 2006 - Caracterização e espectro biológico da vegetação do litoral arenoso do Rio Grande do Norte. Revista de Geografia (Recife) 23, 6686.

amanitaceae.org - 2014.

Bas C. 1969 - Morphology and subdivision of Amanita and a monograph on its section Lepidella. Persoonia 5, 285-579.

Corner EJH, Bas C. 1962 - The genus Amanita in Singapore and Malaya. Persoonia 2, 241-304.

Freire MSB. 1990 - Levantamento florístico do Parque Estadual das Dunas do Natal. Acta Botanica Brasilica 4, 41-69.

Grgurinovic CA. 1997 - Large Fungi of South Australia. The Botanic Gardens of Adelaide and State Herbarium, Adelaide.

Kornerup A, Wanscher JH. 1978 - Methuen Handobook of Colour. $3^{\text {rd }}$ ed. - Eyer Methuen, London.

Menolli Jr. N, Capelari M, Baseia IG. 2009 - Amanita viscidolutea, a new species from Brazil with a key to Central and South American species of Amanita section Amanita. Mycologia 101, 395-400.

Miller Jr. OK. 1992 - Three new species of Amanita from Western Australia. Mycologia 84, 679686.

Reid DA. 1980 - A monograph of the Australian species of Amanita Pers. ex Hook. (Fungi). Australian Journal of Botany, Supplementary Series 8, 1-96.

Smith SE, Read D. 2008 - Mycorrhizal Symbiosis. 3th ed. Academic Press, New York.

Sulzbacher MA, Giachini AJ, Grebenc T, Silva BDB, Gurgel FE, Loiola MIB, Neves MA, Baseia IG. 2013 - Survey of an ectotrophic sand dune in the Northeast Brazil. Mycosphere 4, 11061116.

Tedersoo L, May TW, Smith ME. 2010 - Ectomycorrhizal lifestyle in fungi: global diversity, distribution, and evolution of phylogenetic lineages. Mycorrhiza 20, 217-263.

Thiers B. 2015 [continuously updated] - Index Herbariorum: A global directory of public herbaria and associated staff. New York Botanical Garden's Virtual Herbarium. <http://sweetgum.nybg.org/ih/> accessed 13 February 2015.

Tulloss RE. 2000 - Note sula metodologia per lo studio del genere Amanita (Agaricales). Boletino del Gruppo Micologico G. Bresadola 43, 41-58.

Tulloss RE, Lindgren JE. 2005 - Amanita aprica - a new toxic species from western North America. Mycotaxon 91, 193-205.

Wartchow F, Maia LC. 2007 - The Neotropical Amanita crebresulcata Bas: new citation from Northeast Brazil. Hoehnea 34, 131-134.

Wartchow F, Tulloss RE, Cavalcanti MAQ. 2007 - The discovery of Amanita lilloi in Brazil. Mycotaxon 99, 167-174.

Wartchow F, Tulloss RE, Cavalcanti MAQ. 2009 - Amanita lippiae: a new species from the semiarid caatinga region of Brazil. Mycologia 101, 864-870. 
Wartchow F, Maia LC, Cavalcanti MAQ. 2013 - Studies on Amanita (Agaricomycetidae, Amanitaceae) in Brazil: two yellow gemmatoid taxa. Nova Hedwigia 96: 61-71.

Wolfe BE, Kuo M, Pringle A. 2012a - Amanita thiersii is a saprotrophic fungus expanding its range in the United States. Mycologia 104, 22-33.

Wolfe BE, Tulloss RE, Pringle A. 2012b - The irreversible loss of a decomposition pathways marks the single origin of an ectomycorrhizal symbiosis. PLOSONE 7, e39597. doi:10.1371/journal.pone.0039597

Wood AE. 1997 - Studies in the genus Amanita (Agaricales) in Australia. Australian Systematic Botany 10, 723-854.

Yang Z-L. 1997 - Die Amanita-Arten von Südwestchina. Bibliotheca Mycologica 170, 1-240. 